Arab Univ. J. Agric. Sci., Ain Shams Univ., Cairo, 13(2), 207-217, 2005

\title{
A TAXONOMIC STUDY OF THE GENUS TRIBULUS L. IN EGYPT \\ II- HISTOLOGICAL FEATURES
}

[12]

\author{
Kadria A. Ahmed ${ }^{1}$ and Amaal H. Mohamed ${ }^{1}$
}

\begin{abstract}
Comparative detailed vegetative anatomical investigation for stems, leaves and foliar details of the 7 studied taxa of the genus Tribulus in Egypt has been carried out in order to its reclassification based on internal structures. Accurate drawings for each of the studied organs are outlined into cumulative plates. Also an artificial indented dichotomous key has been constructed. Variation in number of basal vascular bundles ( 2 or 1 ) into the small leaflet-blade within the large leaf is utilized in classifying the studied taxa into two Groups. The $1^{\text {st }}$ contained 5 taxa with 2 main bundles while the $2^{\text {nd }}$ included 2 taxa each with single and unique basal bundle/small leaflet. Members of Gp.I are distinguished according to differences in : phloem \& cambium characters, presence of 2 distinct glandular trichome types, stem outline \& vascular cylinder contents, no. of petiolar vascular strands from base to apex, type of cuticle, type of pericyclic sclerenchymatous patches and others. On the other hand, variation in nature of starch sheath cells (from storing crystals to empty) and presence or absence of schizogenous carnals in pith are found diagnostic in separating both members in Gp. II.
\end{abstract}

Key Words: Gennus Tribulus L., Histological features

\section{INTRODUCTION}

In the previous part of this study (Ahmed and Mohamed, 2005); morphological features of seven taxa belong to the genus Tribulus in Egypt were investigated. In the present paper however, the taxonomic study of this genus is completed and an intensive microscopical analysis is carried out, where the histological features of these seven taxa of Tribulus are studied. Both of the morphological and histological information obtained from this study might be valuable for a new proposal system of Tribulus taxonomy.

Solereder (1908) stated that the vascular system in the petiole of Tribulus is distinguished by a principal system composed of 4-6 bundles and an auxiliary system consisting of 2 lateral bundles which are situated towards the upper side. Metcalfe \& Chalk (1950) gave detailed anatomical characters for stem and leaf of Tribulus. Khalifa (1968) studied the anatomical features for 3 species of the genus Tribulus in Egypt.

1- Botany Department, Faculty of Science (Girls), Al-Azhar University, Nasr City, Cairo, Egypt.

(Received October 23, 2004)

(Accepted December 27, 2004) 
Hickey (1973) and Fisher \& Evert (1982) indicated that; in the petiole, the venation has a distinctive vasculature in which the central cylinder is interrupted and accompanied with 2 or more much smaller collateral veins in the lateroadaxial position. In the stem, there is unusual arrangement of broad radial bands of vessels and fibres. Leaf with $\mathrm{C}_{4}$; kranz arrangement of the mesophyll, the distinct bundle sheath and abaxial layer of water storage cells. It is unusual in having trichomes of 2 markedly different sizes; short and pointed or much longer and wider, growing from a basal plinth of the epidermal cells.

Sheahan and Cutler (1993) described the most characteristic features in the genus Tribulus and recognized the venation type as important in the leaf systematic studies.

\section{MATERIAL AND METHODS}

For epidermal and foliar details (trichomes), preparations were rendered, transparent with warm lactic acid before direct examination. For anatomical investigations, fresh materials were fixed in F.A.A. (Formalin-glacial Acetic acid$70 \%$ Alcohol) with the ratio 5: 5: $90 \mathrm{v} / \mathrm{v}$. In case of dried herbarium specimens, these were first softened by boiling in water then fixed (Nassar and El-Sahhar, 1998). Stem samples were taken from the $2^{\text {nd }}$ and $4^{\text {th }}$ internodes below the apex while leaf samples were taken from the $1^{\text {st }}$ basal pair of leaflets within the large leaf.

Stem samples were hand sectioned at $20-25 \mu \mathrm{m}$ whereas petiole and leaflet blade were serially microtomed at 10 $15 \mu \mathrm{m}$ after being embedded in paraffin wax. Sections were stained according to Dilcher (1974). Stem and leaf anatomy as well as foliar trichome types were examined at bench level by the aid of Leitz camera lucida. The anatomical illustrations for the studied species were recorded in the form of diagrammatic drawings into cumulative plates (I-III).

The terminology concerning the mesophyll type was given according to Metcalfe \& Chalk (1950) and Fahn (1974). The isolateral leaf type was that in which palisade is oriented on both sides and ranged between 1-2 layers in thickness being continuous at wings. The terminology concerning the kranz anatomy $\left(\mathrm{C}_{4}\right)$ is used to indicate that there is a bundle sheath encircling the veins and the mesophyll cells are closely surrounding the cells of this sheath (Laetsch, 1974). The following key is provided for the different anatomical tissues in both stem and leaf of the studied taxa. 


\section{RESULTS AND DISCUSSION}

\section{(1) Stem Anatomy: (Plate I)}

Outline in cross section: terete; Fig. 1. (Tribulus terrestris), quadrangular; Fig. 2 (T. pentandrus), rectangular; Fig.3 (T. macropterus, T. megistopterus) and \pm ovoid; Fig. 4 (the remainders).

Epidermal cells: tangentially elongated (T. terrestris), papillose (T. pentandrus, T.megistopterus \& T.kaiseri) and tangential + papillose (the remainders). Cuticle warty in T.macropterus while striated in the remainders.

Cortex: may be narrow, Fig. 3 ( $T$. macropterus, T. megistopterus) and wide (the remainders), formed of chlorenchyma + paren.; Fig. 4 (T. kaiseri), collenchyma + chloren.; Fig. 3 (T. macropterus, T. megistop- terus) and collenchyma + parenchyma (the remainders). Endodermal layer: either of radially elongated cells (T. terrestris, $T$. terrestris var. bicornutus \& T. mollis) or tangentially elongated (the remainders). These are either full with druses (T. kaiseri) or not (the remainders).

Pericyclic sclerenchymatous patches capping vascular bundles, either composed of: sclereides (stone cells), Fig. 3 (T. macropterus) or fibres (the remainders).

Vascular cylinder composed of, separate collateral vascular bundles of normal growth, these are either 16-18 ones; Fig. 4 (T. terrestris var. bicornutus, T. megistopterus \& T. kaiseri) or 19-21 (the remainders). Phloem: either of obvious elements in wide region, Fig. 1 (T. terrestris, T. terrestris var. bicornutus) or of depressed elements in narrow region (the remainders). Fascicular cambium: either multilayered (T. terrestris, var. bicornutus) or few layered (the remainders). Xylem, usually of numerous wide vessels and few xylem parenchyma.

Pith may be heterogenous of lignified and nonlignified parenchyma (T. macropterus) while homogenous of nonlignified parenchyma (the remainders). Druses and solitary crystals are widespread in both cortex and pith parenchyma in all the studied spp. while schizogenous canals are restricted to T.terrestris var. bicornutus, T. pentandrus \& T. macropterus.

\section{(2) Leaf Anatomy : (Plate II)}

\section{A- Petiolar Vasculature (PI. II, Figs. 1 \& 2)}

The basal vascular supply is always recorded into a central cylinder of separate small vascular strands. These may be, 5 (Fig. 1a) in T. megistopterus, 7 (Fig. 1b) in T. terrestris var. bicornutus, T. mollis and 6 (Fig. $1 \mathrm{c}$ ) in the remainders. The apical vascular supply becomes of either 8 v. strands (Fig. 2 a) in T. terrestris var. bicornutus, T. macropterus or 7 (Fig. 2 b) in the remainders. Accordingly, number of v. strands allover the whole length of petiole is either constant from base to apex (7: 7) in T. mollis or increased in the remainders. Subpalisade cells or $\mathrm{C}_{4}$ arrangement are usually recorded around the apical lateral strands as in (Fig. 2a) except in T. terrestris, T. megistopterus (Fig. 2b) at which they are absent. 
Fig. 1. Terete,

Fig. 3. \pm rectangular,
Fig. 2. quadrangular Fig. 4. \pm ovoid 
Fig. 1. Basal vasculature; a-5 vascular strands, b-7 v. strands, c-6 v. strands Fig. 2. Apical vasculature; a-8 v. strands; b-7 v. strands 


\section{B- Blade Vasculature : (PL. II Cont.) \\ i- Small leaflet blade: (PI. II, Figs. 3 \& 4)}

Usually asymmetric, the abaxial palisade at mid rib region, is either continuous; Fig. 3 a (T. mollis, T. kaiseri) or discontinuous; Fig. 3 b (the remainders).

Basal vasculature: of one main bundle (Fig. 4 a) in $T$. pentandrus, T. kaiseri while of 2 main ones (Fig. 4 b) in the remainders. On the other hand, the accompanied smaller lateral bundles (veinlets) are either; one in most species or rarely 2 (Fig. 4 a) in T.kaiseri. These are either free (Fig. 4 b) in T.terrestris, T.megistopterus \& T.mollis or covered by a sheath of subpalisade cells (Fig. 4 a) in the remainders.

\section{ii- Large leaflet blade: (PI. II, Figs. $5 \& 6)$}

Main vascular bundles, are usually 3 (Fig. 5,a), sometimes 2 (Fig. 5 b) in $T$. terrestris, T.megistopterus, T.mollis. The lateral smaller veinlets are mostly 2 except in case of T. kaiseri (Fig. 6 a) which has only one. These are either; completely sheathed by smaller subpalisade cells (Figs. 5 a $\& 6$ a) in $T$. terrestris var. bicornutus, T. pentandrus, T. macropterus $\&$ T. kaiseri, partially sheathed (Fig. 5 b) in T.mollis or unsheathed (Fig. 6 b) in $T$. terrestris, T. megistopterus. Druses, recorded in mesophyllic parenchyma.

\section{(3) Foliar Trichome Types: (Plate III)}

Stomata, usually anomocytic, there are 15 different trichome types recorded and identified into Pl. III. at which it is noticed that the trichome types (PI III. Figs. 1,9, 10, 11, 13) are widespread on all the studied spp. with special interest to the type Fig. 10. (stingy trichome) which is considered as a clothing one. The remainder types are varied in distribution as each studied plant is characterized by at least one of such types. 
i- (Figs $3 \& 4$ ): for small leaflet blade, ii- (Figs. $5 \&$ 6): for large leaflet blade Note: Fig. 5 (b), Fig. $6(\mathrm{a} \&$ b) are of the petiole apex (i.e. = blade base) 


\section{Foliar Trichome Types : (Plate III)}

\section{a- Glandular}

- With unicellular head

1- Stalk unicellular; T.mollis.

2- Stalk bicellular, uniseriate; T.kaiseri.

3- Stalk tricellular, uniseriate; T.macropterus.

- With bicellular head

4- Stalk unicellular; T. terrestris var. bicornutus.

- With multicellular head

5- Stalk unicellular; T. megistopterus.

6- Stalk bicellular, uniseriate; T. terrestris var. bicornutus.

7- Stalk bicellular, biseriate; T. pentandrus.

8- Stalk multicelluar, biseriate; T. terrestris.

\section{b- Non glandular}

\section{- unicellular}

9- Thin-walled papillose; T. pentandrus.

10- Thick-walled with rounded base and long tapered apex, full with dark secretion (stingy trichome); T. kaiseri.

\section{- bicellular}

11- With normal basal cell and papillosed apical cell; T.megistopterus.

12- With broad inflated basal cell and short tapered apical cell; T.mollis.

13- With short obconical basal cell and long tapered perpendicular apical cell; $T$. macropterus.

14- With short obconical basal cell and very long inflated, obtuse apical cell; T. terrestris var. bicornutus.

\section{- multicellular}

15- Uniseriate with short obconical basal cell and short tapered apical cell; T. terrestris. 
Histological features of Tribulus L.

Arab Univ. J. Agric. Sci., 13(2), 2005 


\section{Key for Species}

A- Small leaflet-blade with two basal vascular bundles

B-Phloem obvious, cambium multilayered, glandular trichomes with unicellular head, bicellular uniseriate stalk and that with multicellular head \& multicellular biseriate stalk (Pl. III, Figs. 2 \& 8), present.

C- Stem outline terete, epidermal cells tangentially elongated, vascular cylinder of 19-21 bundles, non glandular multicellular uniseriate trichome with short obconical basal cell and short tapered apical cell. (Pl. III, Fig. 15.) present. . .

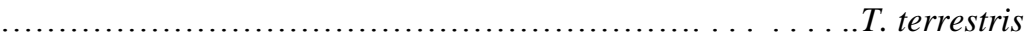

CC- Stem outline ovoid, epidermal cells mixed (tang. + papi.), v.cylinder of 1618 bundles, above trichome absent....................... terrestris

var. bicorunutus

BB- Phloem depressed, cambium few layered, above trichomes absent

D- Number of petiolar vascular strands constant from base to apex, starch sheath radially elongated, abaxial palisade at mid rib region; continuous. ........................................................... mollis

DD- No. of petiolar v.strands increased from base to apex, starch sheath tangentially elongated, abaxial palisade at mid rib region discontinuous.

E- Cutin warty, stem pericyclic schlerenchymatous patches stony, petiolar lateral v.strands with subpalisade ........................ T. macropterus

EE- Cutin striated, stem pericyclic scl. patches fibred, petiolar lateral v. strands without subpalisade.

.T. megistopterus

AA- Small leaflet blade with one basal v. bundle.

F- In stem; starch sheath crystalloid, pith without schizogenous canals T. kaiseri.

FF- In stem; starch sheath empty, pith with schiz. canals . T. pentandrus

This result is in conformity with that of Hickey (1973), Fisher \& Evert (1982) and Sheahan \& Cutler (1993) who believed that Tribulus has its distinctive anatomical characters regard to; petiole venation, stem and leaf characters as well as foliar trichome types. 


\section{REFERENCES}

Ahmed Karia, A. and A.H. Mohamed (2005). A Taxonomic Study of the Genus Tribulus L. in Egypt (I-Morphological Features). Arab. Univ. J., Agric. Sci., Ain Shams Univ., Cairo, 13(2):197-206.

Dilcher, D.L. (1974). Approaches to the Identification of Angiosperm Leaf Remains. Bot. Rev. 40(1): 86-116. London, U.K.

Fahn, A. (1974). Plant Anatomy. Ed. 2, pp. 410-412. Pergamon Press. London, U.K.

Fisher, D.E. and R.F. Evert (1982). Studies on the Leaf of Amaranthus reflexus. Amer. J. Bot. (69): 1133-1147.

Hickey, L.J.(1973). A Classification of the Architecture of Dicotyledonous Leaves. Amer. J. Bot. 60: 17-33.

Khalifa, S.F. (1968). Taxonomic Studies on Some Plants Belonging to the Order
Geraniales. 324 pp. M.Sc. Thesis, Bot. Dept., Fac. Sci., Ain Shams Univ., Cairo, Egypt.

Laetsch, W.M. (1974). The $\mathrm{C}_{4}$ Syndrome; A Structural Analysis. Ann. Rev. Plant Physiol., No. 25, pp. 27-52. London, U.K.

Metcalfe, C.R. and L. Chalk (1950). Anatomy of the Dicotyledons, Vol. 1, pp. 40-53, 66 \& pp. 285-291. Clarendon Press, Oxford, U.K.

Nassar, M.A. and K.F. El-Sahhar (1998). Botanical Preparations and Microscope Analysis (Microtechnique), 219 pp. (In Arabic). Academic Book Shop, Dokki, Cairo, Egypt.

Sheahan, M.C. and D.F. Cutler (1993). Contribution of the Vegetative Anatomy to the Systematics of the Zygophyllaceae R. Br. Bot. J. Linn. Soc. 113: 227-262, London U.K.

Solereder, H. (1908). Systematic Anatomy of the Dicotyledons, Vol. 2, p. 850. Clarendon Press, Oxford, U.K. 
بحلة اتحاد الجامعات العربية للدراسات والبحوث الزراعية، جامعة عين شمس، القاهرة ، 13(2)، 207-218، 2005

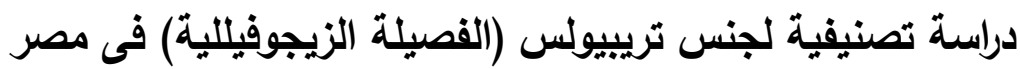

ثانيا: الصفات التثريحية

[12]

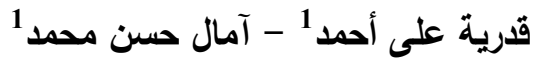 \\ 1- قسم النبات - كلية العلوم (بنات) - جامعة الأزهر - مدينة نصر - القاهرة - مصر حصر
}

وقد تم التفريـق بين الفئات التصنيفية

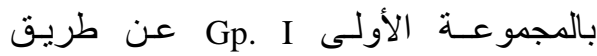

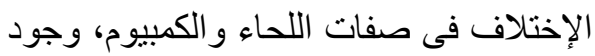

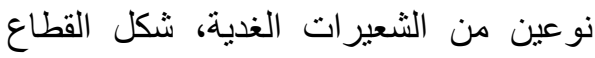

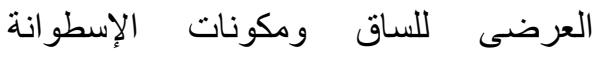
الوعائية، عدد الخيوط الو عائية مـن قاعدة الإنية

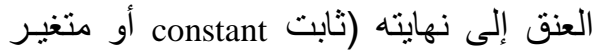
(varied

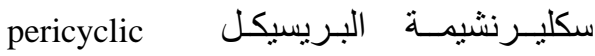

\section{selerenchyma}

كمـا أدى التباين فى طبيعة خلايا طبقة

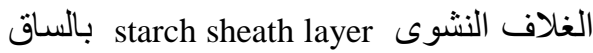

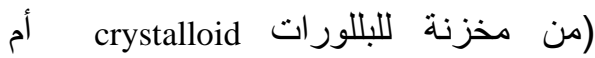
فارغة empty) وكذللك وجود أو غياب

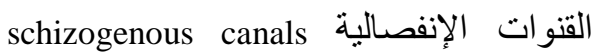
بالنخاع الى سهولة التفريق بين فئتى Gp. II المجمو عة الثانية
تمت دراسة تشريحية مقارنة ومفصلة لسوق وأوراق وكذلك الثعيرات السطحية للسبعة فئات التصينيفية المدروسة من جنس التسرات السطية

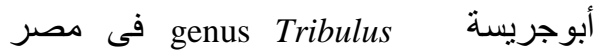
بغرض إعادة تصنيفه طبقاً للصفات التشريحية. وقد سجلت نتائج الدراسة على هيئة

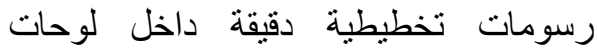
مجمعة لكل من الأعضاء المدروسة. كما تم دمات

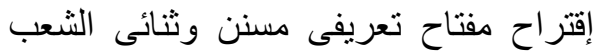

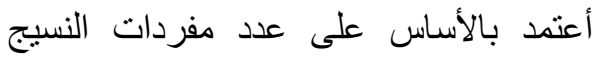
main vascular bundles الوعائى الأساسيى بقاعدة الوريقة الصغرى الإسى (بيداية الورقة الكبيرة) فى تصنيف النباتات

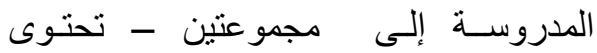

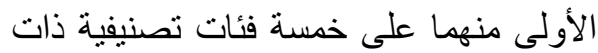

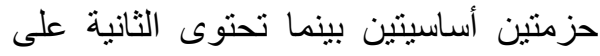
فيتتين تصنيفيتين ذات حزمة و احدة. تحكيم: ا.د سامى عبد القوى ا.بد قاسم فؤاد السحسار 